\title{
Word of Mouth Marketing in Mouth and Dental Health Centers towards Consumers
}

\author{
Aykut EKIYYOR \\ Gazi University \\ Faculty of Economisc and Administrative \\ Sciences, Department of Healthcare \\ Management, Ankara, Turkey \\ aykutekiyor1974@yahoo.com
}

\author{
E. Asuman ATílLA \\ Gazi University \\ Faculty of Economics and Administrative \\ Sciences, Department of Healthcare \\ Management, Ankara, Turkey \\ asumanatilla@gmail.com
}

\begin{abstract}
Influencing the shopping style of others by passing on the experiences of goods purchased or services received is a way of behavior that has its roots in history. The main objective of this research is to analyze the effects of demographic factors within the scope of word of mouth marketing on the choices of mouth and dental health services. Consumers receiving service from mouth and dental health centers of the Turkish Republic Ministry of Health constitute the environment of the research. The research conducted in order to determine the mouth and dental health center selection of consumers within the scope of word of mouth marketing. The research has been conducted in Ankara through simple random sampling. The sample size has been determined as 400 . In terms of word of mouth marketing which has been determined as the third hypothesis of the study, as a result of the analysis of the statistical relationship between mouth and dental health center preference and demographic factor groups, it has been determined that there is a meaningful difference in terms of age, level of education, level of income and some dimensions of marital status and that no meaningful difference has been found in terms of gender. It has been attempted to determine the importance of word of mouth marketing in healthcare services.
\end{abstract}

Key Words: Word of Mouth Marketing. Mouth and Dental Health. Consumer. Health Service. Marketing.

\section{Introduction}

The concept of word of mouth marketing could be defined as the advice and recommendation of consumers who have purchased a good or service to others. This way, positive or negative, informal information about a good or service spread among people (Gulmez, 2008, p.318). While constituting the target population of mass communication, consumers also stand in a non-verbal and non-structural communication network among themselves (Barutcu, 2011, p.9). People want to 
communicate when they want to praise or vilify a good or service (Kutluk and Avcikurt, 2014, p.614).

As a matter of fact, this way of communication is one of the oldest marketing techniques. For example, if the consumer has an experience about the good, he will pass on the positive or negative information to friends who purchase or use that good frequently (Argan, 2006, p.233). The most distinct characteristics of this type of communication are sincerity, honesty and reliability to the source. It is a marketing technique that aims to pass on the content to be spread to the target population in the most appropriate and since method by using non-traditional communication channels (Ulusoy, 2014). Word of mouth marketing is not marketing to consumers but marketing with consumers. People may be derived to purchase something through the influence of a small portion of announcements, advertisements and telephone calls. However, the same people respect the majority of advice they receive from their friends (http://pazarlama.stratejileri.com, 2014).

When the types of word of mouth marketing are analyzed, we can talk about positive or negative word of mouth marketing communication types, as illustrated below.

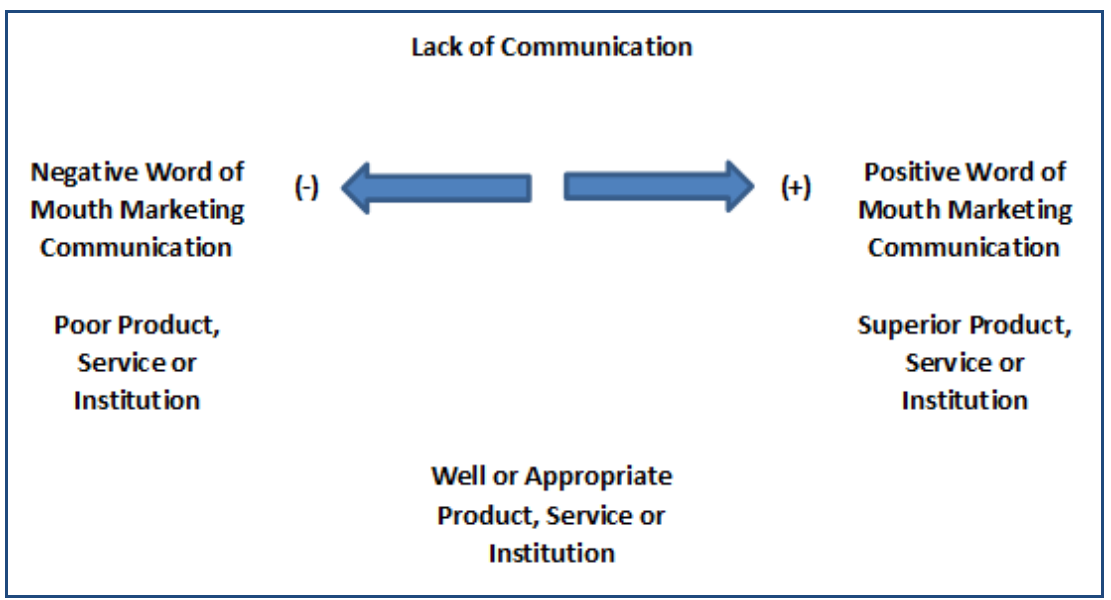

Fig. 1. Types of Word of Mouth Marketing (Odabasi and Baris, 2006)

Positive word of mouth marketing occurs when news that the institution desires is passed on to others. Negative word of mouth marketing on the other hand occurs when people pass on their negative experiences to others after purchasing something. This causes a negative effect on the company's reputation and financial structure (Aba, 2011, p.50).

Theoretically, when there is going to be a word of mouth marketing, the first step will be to reach the suitable $10 \%$ of the society whom we refer to as "information transmitter". We would want to start our campaign with these people because the characteristics of these people enable the intended message to be transmitted to wide masses at great speed. The senses of information transmitters are open and have a wide social surrounding. They like sharing their opinions with the people around them. When they feel themselves special, it is easy for them to become the voluntary ambassadors of the brand that has affected them. This way, brands will pass on their messages in the most effective channel that is inevitable for it to be considered (https://www.myenocta.com, 2014). 


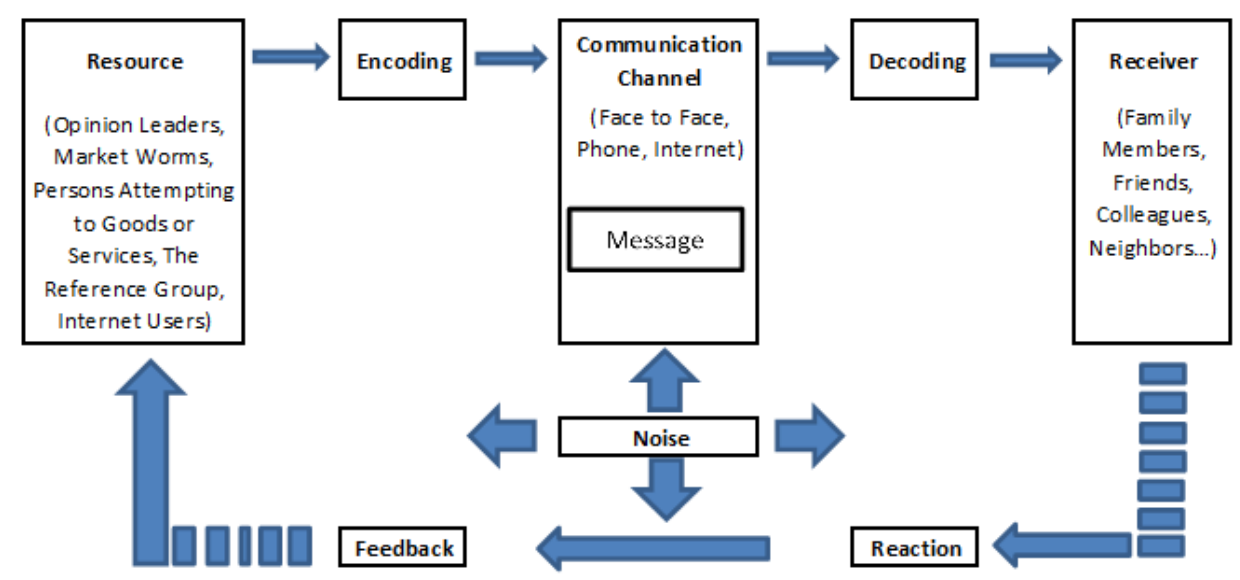

Fig. 2. Information Transmitter (Karaoglu, 2010)

In the various research conducted, it has been found that the effect of word of mouth marketing differs according to the product groups. In a research in 1991, Murray found that buyers trust personal information and source of information when they are deciding on purchasing services when compared with goods. Within this scope, when buyers choose to purchase something out of necessity they rely on word of mouth marketing especially on services on which they have no idea or they don't know their quality. Buyers try to gather information about these services which they did not have the opportunity to try before. Advice people give about a health center or a physician effect the choices of buyers and provide them with an idea about the service. It is of major importance for health care providers to establish a positive image about their services and to have people who have tried their services to give positive advice to those who have not yet tried their services (Yilmaz, 2011, p.5). The common opinion of administrators, market researchers and sociologists is that consumers are in an interaction through word of mouth marketing and that this word of mouth, along with advertisements, has a very strong influence on the customer. For example, it has been determined that more than $40 \%$ of American consumers consult their family and close friends when making selections on law, automotive and physicians and act accordingly (Hogan et al, 2004, p.272).

\section{Methods}

The main objective of this research is to analyze the effects of demographic factors within the scope of word of mouth marketing on the choices of mouth and dental health services. The subject of the research is to present the concept of word of mouth marketing in the health sector, to determine the opinions of consumers which lead to the selection of mouth and dental health centers. The question of "Does word of mouth marketing have an effect on the mouth and dental health center preference?" constitutes the main problem of the research.

Consumers receiving service from mouth and dental health centers of the Turkish Republic Ministry of Health constitute the environment of the research. The research conducted in order to determine the mouth and dental health center selection of consumers within the scope of word of mouth marketing. The research has been conducted in Ankara through simple random sampling. The sample size in the research has been measured as 384 by taking level of trust as $95 \%$ and error margin as $\pm \% 5$ 
(Yukselen, 2006, p.62). The sample size has been determined as 400 in order to decrease error margin. This way, level of trust will increase and error margin will decrease. The research has been conducted using a survey form. The survey form used in the research consists of three parts. In the first part, there are 5 questions to determine the demographic characteristics of the students. In the second part of the survey form, there are 7 questions to determine the characteristics related to taking advice or not and the people from whom advice is taken. In the third part of the survey form, there are 29 statements to measure the effects of the immediate surroundings in the consumers' selection of mouth and dental health centers. Moreover, there are 2 statements intending to determine the effects of saving time and money in word of mouth marketing. The third part of the survey form consists of a total of 31 questions. The survey form is according to the 5 point likert scale; 5: "I strongly agree", 4: "I agree", 3: "I am not sure", 2: "I agree", and 1: "I strongly disagree". The reliability analysis has been determined through the calculation of Alpha coefficient (Cronbach's Alpha). Because the alpha coefficient used for the reliability of the scale is determined as 0.932 , it has been accepted that the internal consistency of the scale is ensured.

The following hypothesis related to the selections of mouth and dental health centers within the scope of word of mouth marketing has been tested.

H1: There is a significant statistical difference in the selection of mouth and dental health centers on the dimensions of word of mouth marketing and whether to take advice or not.

$\mathrm{H} 2$ : There is a meaningful statistical relationship between the selection of mouth and dental health centers and immediate surrounding as well as satisfaction within the scope of word of mouth marketing.

H3: There is a meaningful statistical difference between the selection of mouth and dental health centers and demographic factor groups within the scope of word of mouth marketing.

In the analysis of the data obtained at the end of the survey, hypothesis determined using pearson correlation, $t$ test, one-way analysis of variance (anova) and regression analysis have been tested.

\section{Findings}

When the consumers participating in the research are analyzed in terms of their demographic characteristics: it has been understood that $60.8 \%$ are female, $39.2 \%$ are male; $34.8 \%$ are between the ages of $30-39,28.2 \%$ are between the ages of $40-49$, $20.3 \%$ are between the ages of $19-29,9.5 \%$ are between the ages of $50-59,8.8 \%$ are 18 and below; $34.0 \%$ have a high school degree, $20.8 \%$ have a graduate degree, $16.0 \%$ have an associate degree, $12.5 \%$ have a primary school degree, $11.3 \%$ have a secondary school and $5.5 \%$ have a postgraduate degree.

When the level of incomes of the consumers participating in the research are analyzed; it has been seen that $43.3 \%$ earn below 1000 TL and below, $18.3 \%$ earn between 1001 and 1499 TL, 11.8\% earn between 3000 and 3499 TL, 9.8\% earn between 2500 and 2999 TL, 8.8\% earn between 1500 and 1999 TL, 8.3\% earn between 2000 and 2499 TL. In terms of marital status, it has been determined that $69.5 \%$ are married and $31.5 \%$ are single. 
$72.8 \%$ of the participants have indicated that they take advice before going to a mouth and dental health center. When the situations of the consumers within the last 6 months are analyzed, $62 \%$ have stated that they consciously took advice, $42.5 \%$ unconsciously took advice, $64.3 \%$ were satisfied from the service which they had received advice on, $69.2 \%$ consciously gave advice and $78.5 \%$ have stated that they have been asked for advice.

Consumers were asked about the people they ask for advice and were told that they could mark more than one option. A majority of the consumers have stated that they take advice from friends $(47.3 \%)$, health center workers $(47 \%)$, relatives $(32.5 \%)$ and parents $(26.5 \%)$ about mouth and dental health centers.

A reliability analysis has been conducted in order to determine the consistency of the variables with each other and the extent to which the scale reflects the related problem. In this study, the Cronbach Alpha coefficient was 0.932 ensuring high reliability. In order to make the variables in the third part of the survey statistically meaningful, they have been separated into dimensions. The dimensions determined are the opinions of the immediate surrounding (questions 1-7), reliability of the immediate surrounding (questions 8-11), experience of the immediate surrounding (questions 1215), saving time and money (questions 16-17), the state of satisfaction (questions 18-24) and the state of dissatisfaction (questions 25-31). In order to measure the consistency between the dimensions, pearson correlation coefficients have been analyzed.

\section{Table 1: Relationship Between the Dimensions of Word of Mouth Marketing}

\begin{tabular}{|c|c|c|c|c|c|c|c|}
\hline $\begin{array}{c}\text { Dimensions of } \\
\text { Word of } \\
\text { Mouth } \\
\text { Marketing } \\
\end{array}$ & & $\begin{array}{c}\text { Opinions of } \\
\text { the } \\
\text { immediate } \\
\text { surroundings }\end{array}$ & $\begin{array}{l}\text { Trust of the } \\
\text { immediate } \\
\text { surrounding }\end{array}$ & $\begin{array}{l}\text { Experience of } \\
\text { the immediate } \\
\text { surroundings }\end{array}$ & $\begin{array}{c}\text { Saving } \\
\text { time and } \\
\text { money }\end{array}$ & Satisfaction & Dissatisfaction \\
\hline \multirow{3}{*}{$\begin{array}{l}\text { Opinions of the } \\
\text { immediate } \\
\text { surroundings }\end{array}$} & $\mathrm{R}$ & 1 & .604 & .649 & .592 & .603 & .420 \\
\hline & Sig. (p) & & .000 & .000 & .000 & .000 & .000 \\
\hline & $\mathrm{N}$ & 400 & 400 & 400 & 400 & 400 & 400 \\
\hline \multirow{3}{*}{$\begin{array}{l}\text { Trust of the } \\
\text { immediate } \\
\text { surroundings }\end{array}$} & $\mathrm{R}$ & .604 & 1 & .659 & .563 & .624 & .391 \\
\hline & Sig. (p) & .000 & & .000 & .000 & .000 & .000 \\
\hline & $\mathrm{N}$ & 400 & 400 & 400 & 400 & 400 & 400 \\
\hline \multirow{3}{*}{$\begin{array}{l}\text { Experience of the } \\
\text { immediate } \\
\text { surroundings }\end{array}$} & $\mathrm{R}$ & .649 & .659 & 1 & .587 & .651 & .514 \\
\hline & Sig. (p) & .000 & .000 & & .000 & .000 & .000 \\
\hline & $\mathrm{N}$ & 400 & 400 & 400 & 400 & 400 & 400 \\
\hline \multirow{3}{*}{$\begin{array}{l}\text { Saving time and } \\
\text { money }\end{array}$} & $\mathrm{R}$ & .592 & .563 & .587 & 1 & .545 & .538 \\
\hline & Sig. (p) & .000 & .000 & .000 & & .000 & .000 \\
\hline & $\mathrm{N}$ & 400 & 400 & 400 & 400 & 400 & 400 \\
\hline \multirow[t]{3}{*}{ Satisfaction } & $\mathrm{R}$ & .603 & .624 & .651 & .545 & 1 & .527 \\
\hline & Sig. (p) & .000 & .000 & .000 & .000 & & .000 \\
\hline & $\mathrm{N}$ & 400 & 400 & 400 & 400 & 400 & 400 \\
\hline \multirow[t]{3}{*}{ Dissatisfaction } & $\mathrm{R}$ & .420 & .391 & .514 & .538 & .527 & 1 \\
\hline & Sig. (p) & .000 & .000 & .000 & .000 & .000 & \\
\hline & $\mathrm{N}$ & 400 & 400 & 400 & 400 & 400 & 400 \\
\hline
\end{tabular}

$\mathrm{p}<0.05$

As it is seen in Table 1, there is a meaningful relationship between the dimensions determined within word of mouth marketing $(\mathrm{p}<0.05)$. According to the survey results, there are meaningful relationships between the opinion of the immediate surrounding and the trust of the immediate surrounding ( $\mathrm{r}: .604 ; \mathrm{p}<0.05)$, experience of the immediate surrounding ( $\mathrm{r}: .649 ; \mathrm{p}<0.05)$, saving time and money $(\mathrm{r}: .592 ; \mathrm{p}<0.05)$, satisfaction $(\mathrm{r}: .603 ; \mathrm{p}<0.05)$ and dissatisfaction $(\mathrm{r}: .420 ; \mathrm{p}<0.05)$. It has been determined that there is correlation between the trust of the immediate surrounding and 
the experience of the immediate surrounding which have been analyzed in the second dimension ( $\mathrm{r}: .659 ; \mathrm{p}<0.05)$, saving time and money $(\mathrm{r}: .563 ; \mathrm{p}<0.05)$, satisfaction $(\mathrm{r}$ : $.624 ; \mathrm{p}<0.05)$ and dissatisfaction $(\mathrm{r}: .391 ; \mathrm{p}<0.05)$. It has been understood that there is a relationship between the experience of the immediate surrounding and saving time and money (r: .587; $\mathrm{p}<0.05)$, satisfaction $(\mathrm{r}: .651 ; \mathrm{p}<0.05)$ and dissatisfaction ( $\mathrm{r}: .514$; $\mathrm{p}<0.05)$ which are in the third dimension. There is a relationship between saving time and money and satisfaction $(\mathrm{r}: .545 ; \mathrm{p}<0.05)$ and dissatisfaction $(\mathrm{r}: .538 ; \mathrm{p}<0.05)$ in the fourth dimension. There is a relationship between satisfaction and dissatisfaction ( $\mathrm{r}$ : $.527 ; \mathrm{p}<0.05)$ in the fifth dimension. It has been established that the questions in the survey are consistent with each other and that the scale used is reliable.

In the research, word of mouth marketing has been considered in terms of taking advice or not in the selection of mouth and dental health centers. In the survey, consumers were asked their state of taking advice in the selection of mouth and dental health centers. In accordance with the responses of the participants, the averages of the dimensions constituting the mouth and dental health center preference and taking advice or not has been analyzed. With this aim, $t$ test has been conducted in order to determine the effect of taking advice or not in the mouth and dental health center preference and whether there is a difference between the dimensions.

The research hypotheses have been tested and are explained below.

Table 2: Results of Mouth and Dental Health Center Preference in Terms of Taking Advice or not

\begin{tabular}{|c|c|c|c|c|c|c|c|}
\hline $\begin{array}{c}\text { DIMENSIONS OF } \\
\text { WORD OF } \\
\text { MOUTH } \\
\text { MARKETING }\end{array}$ & $\begin{array}{l}\text { Taking } \\
\text { advice }\end{array}$ & $\mathbf{N}$ & $\mathbf{X}$ & $\mathbf{S}$ & $\mathbf{t}$ & $\mathbf{F}$ & p \\
\hline \multirow{2}{*}{$\begin{array}{l}\text { Opinion of the } \\
\text { immediate } \\
\text { surrounding }\end{array}$} & Yes & 291 & 3.835 & .770 & 2.732 & 14.488 & .000 \\
\hline & No & 109 & 3.579 & .979 & 2.454 & & \\
\hline \multirow{2}{*}{$\begin{array}{c}\text { Trust of the immediate } \\
\text { surrounding }\end{array}$} & Yes & 291 & 3.748 & .845 & .674 & .217 & .642 \\
\hline & No & 109 & 3.684 & .884 & .660 & & \\
\hline \multirow{2}{*}{$\begin{array}{l}\text { Experience of the } \\
\text { immediate } \\
\text { surrounding }\end{array}$} & Yes & 291 & 3.903 & .751 & 2.729 & 6.061 & .014 \\
\hline & No & 109 & 3.663 & .864 & 2.562 & & \\
\hline \multirow{2}{*}{$\begin{array}{c}\text { Saving time and } \\
\text { money }\end{array}$} & Yes & 291 & 3.638 & .889 & 1.779 & 3.316 & .069 \\
\hline & No & 109 & 3.454 & .992 & 1.692 & & \\
\hline \multirow[t]{2}{*}{ Satisfaction } & Yes & 291 & 3.791 & .657 & 1.825 & 10.114 & .002 \\
\hline & No & 109 & 3.649 & .791 & 1.677 & & \\
\hline \multirow[t]{2}{*}{ Dissatisfaction } & Yes & 291 & 3.467 & .757 & 1.478 & 1.967 & .162 \\
\hline & No & 109 & 3.345 & .677 & 1.554 & & \\
\hline
\end{tabular}

$\mathrm{p}<0.05$

Results of Mouth and Dental Health Center Preference in Terms of Taking Advice or not within the consumers participating in the research have been demonstrated in table 2. According to the result, it has been understood that there is a meaningful relationship between the opinion of the immediate surroundings, experience of the immediate surrounding and satisfaction dimensions $(p<0.05)$. Thus, whether the participants take advice or not affect the mouth and dental health center preference in terms of the opinion of the immediate surroundings, experience of the immediate surrounding and satisfaction dimensions.

In this dimension, the averages of those taking advice turned out to be higher. A meaningful relationship was not found between the trust of the immediate surroundings, 
saving time and Money and satisfaction dimensions. The H1 hypothesis of lour research has been accepted in terms of three dimensions (opinions of the immediate surroundings, experience of the immediate surroundings, satisfaction)

In the testing of the research's second hypothesis, regression analysis, anova and $t$ tests have been conducted in order to establish the relationship between the opinions of the immediate surroundings, trust of the immediate surroundings, experience of the immediate surroundings and saving time and money with satisfaction. Regression analysis is used in order to measure the relationship between two or more variables.

At the end of the regression analysis, $\mathrm{R}=.725, \mathrm{R}^{2}=.526$. These values explain the relationship between word of mouth marketing dimensions and satisfaction. The model expresses $52.6 \%$ of the variance. At the end of the anova test $\mathrm{F}=109.721 \mathrm{p}=.000$.

\section{Table 3: The Relationship Between Word of Mouth Marketing Dimensions and Satisfaction}

\begin{tabular}{|l|c|c|c|}
\hline \multicolumn{1}{|c|}{$\begin{array}{c}\text { WORD OF MOUTH MARKETING } \\
\text { DIMENSIONS }\end{array}$} & B & t & F \\
\hline Opinion of the immediate surrounding & .161 & 3.879 & .000 \\
\hline Trust of the immediate surrounding & .202 & 4.998 & .000 \\
\hline Experience of the immediate surrounding & .259 & 5.628 & .000 \\
\hline Saving time and money & .091 & 2.568 & .011 \\
\hline
\end{tabular}

$\mathrm{p}<0.05$

According to table 3, there is a positive relationship between the word of mouth marketing dimensions; opinions of the immediate surrounding (.161), trust of the immediate environment (.202), experience of the immediate surrounding (.259), saving time and money (.091) and satisfaction. It is understood that there is a meaningful relationship according to $t$ and $F$ values in terms of statistics $(p<0.05)$. In the selection of mouth and dental health center, making use of the opinions, trust and experience of the immediate surroundings satisfy consumers. Moreover, it also provides time and money saving. According to the findings, $\mathrm{H} 2$ hypothesis has been accepted.

A one way variance analysis (anova) has been conducted in order to test the relationship between the age groups of the participants and their preferences in mouth and dental health centers. Because the unit number of the group with participants at the age of 60 and above is low, it has been combined with age group 50-59. In terms of the age groups, it has been determined that there is a 5\% meaningful difference in the dimensions of trust of the immediate surroundings, time and money saving and dissatisfaction $(p<0.05)$. No meaningful difference has been found in the other dimensions. In the trust of the immediate surroundings, the 18 and below age group has a lower average than the other age groups. In time and money saving, the 50-59 age group is low when compared with the averages of the other age groups. In the dimension of dissatisfaction, the average of the 50-59 age group is lower.

A one-way variance analysis (anova) has been conducted in order to measure the effect of income on the mouth and dental health center preference in terms of dimensions. Because the unit value of those with an income of $1500 \mathrm{TL}$ and above is 
low, they have been combined with the group between the range of 3000-3499 TL. According to the analysis results, it has been determined that there is a 5\% meaningful difference in terms of income level and preferences on mouth and dental health centers. Level of income is effective in the selection of mouth and dental health centers in terms of dimensions. When we look at the averages of the dimensions in the mouth and dental health center preference, it is understood that the averages of the participants with an income of 2500-2999 TL is high.

In the study, $t$ test has been conducted in order to analyze the relationship between the dimensions of mouth and dental health center preferences and the marital status of the participants. According to the test conducted $(\mathrm{t}=-1.024 ; \mathrm{p} .012)$, it has been seen that there is a meaningful difference between marital status and mouth and time-money saving $(\mathrm{p}<0.05)$. When we look at the average values, time-money saving average of married participants is higher than single participants.

As a result of the analysis of the statistical relationship between mouth and dental health center preference and demographic factor groups, which was determined as the third hypotheses of the study, it has been found that there is a meaningful difference in terms of age, level of education, level of income and some dimensions of marital status while there is no meaningful difference in terms of gender. The third hypothesis of the study has been accepted in terms of age, level of education, level of income and some dimensions of marital status, and has been refused in terms of gender.

\section{Results}

Today, businesses experience difficulty in reaching, informing and persuading consumers and endure high costs. While the diversifying communication methods and differing consumer expectations are reducing the effects of traditional means of communication, the effect of word of mouth marketing is increasing. Consumers tend to refer to people who have tried or have information about the good or service. The method that can meet the need stands out to be word of mouth marketing.

It has been concluded that there is a meaningful relationship between the dimensions determined as a result of the pearson correlation coefficient applied to 31 statements established in order to determine mouth and dental health center preference within the scope of word of mouth marketing.

In the research, $72.8 \%$ of the participants have stated that they take advice before going to a mouth and dental health center. A majority of the participants have indicated that they refer to the advice of friends $(47.3 \%)$, people working in a healthcare institution (47\%), relatives $(32.5 \%)$ and parents $(26.5 \%)$.

Out of the variables, the statements that received the highest average are "I will recommend a mouth and dental health center if I am satisfied with it" and "I will go to a mouth and dental health center when I am in need".

The findings after the testing of the study's hypothesis are:

According to the results obtained through the testing of the first hypothesis of the study, it has been understood that there is a meaningful relationship in the opinions of the immediate surroundings, experience of the immediate surroundings and satisfaction dimensions $(\mathrm{p}<0.05)$. Thus, whether the participants take advice or not affect the mouth 
and dental health center preference in terms of the opinions of the immediate surroundings, experience of the immediate surroundings and satisfaction dimensions.

In the evaluation of the study's second hypothesis, there is a positive relationship between the opinions of the immediate surrounding (.161), trust of the immediate surroundings (.202), experience of the immediate surrounding (.259), time and money saving (.091) and satisfaction dimensions. It is understood that there is a meaningful statistical relationship according to the $t$ and $F$ values $(p<0.05)$. Benefiting from the opinions, trust and experience of the immediate surroundings satisfy consumers. It also saves time and money for the consumers.

In terms of word of mouth marketing which has been determined as the third hypothesis of the study, as a result of the analysis of the statistical relationship between mouth and dental health center preference and demographic factor groups, it has been determined that there is a meaningful difference in terms of age, level of education, level of income and some dimensions of marital status and that no meaningful difference has been found in terms of gender. The third hypothesis of the study has been accepted in terms of age, level of education, level of income and some dimensions of marital status and has been declined in terms of gender.

\section{Conclusion}

It has been attempted to determine the importance of word of mouth marketing in healthcare services. As a result; it is believed that this study will contribute to literature in terms of comprehending the importance of word of mouth marketing in healthcare services.

When research conducted in order to determine the importance of word of mouth marketing are analyzed, according to a research conducted by Ferguson et al (Ferguson et al, 2006), it has been seen that the people who are referred to most for advice are people who have received service from the same healthcare center and who were satisfied (49\%). In another study conducted at Mayo Clinic by Hathaway and Seltman (Hathaway and Seltman, 2001), it has been determined that $65 \%$ of the customers stated the advice of friends and relatives among the reasons for choosing this clinic.

If we consider the fact that we have also reached the conclusion that taking advice or not effects the preference of mouth and dental health centers in terms of opinion and experience of the immediate surroundings and satisfaction dimensions, the effects of word of mouth marketing in healthcare services on the preferences of customers will clearly be put forward.

If we consider that experiences are taken into consideration in healthcare services where there are abstract characteristics, it should not be forgotten that a number of physical factors such as the center's location, interior design, interest and friendliness of the employees should be at satisfying levels in order to ensure satisfaction. Having satisfied customers share their experiences should be encouraged, the selection reasons of the consumers should be shared with the public through various means of communication. 


\section{References}

Aba G., (2011). "Saglik Hizmetlerinde Agizdan Agiza Pazarlama: Bir Alan Arastirmasi”, Frrat Universitesi Saglik Hizmetleri Dergisi, 6 (16):45-60.

Argan M., Argan Tokay M., (2006). "Viral Pazarlama veya Internet Uzerinde Agizdan Agiza Reklam: Kuramsal Bir Cerceve", Anadolu Universitesi Sosyal Bilimler Dergisi. 6(2): 231-250.

Barutcu S., (2011). "Mobil Pazarlama", Internet Uygulamalari ve Yönetimi Dergisi, 2(1): 5-13.

Ferguson J. R., Paulin M., Leiriao E., (2006). "Loyalty and Positive Word-of-Mouth: Patients and Hospital Personel as Advocates of a Customer- Centric Health Care Organization", Health Marketing Quarterly, 23(3):59-77.

Gulmez M., Editorler: Varinli I., Cati, K., (2008). Agizdan Agiza Iletisim ve Pazarlama: Guncel Pazarlama Yaklasimlarından Secmeler, Detay Yayıncılık, Ankara.

Hathaway M., Seltman K., (2001)." International Market Research at the Mayo Clinic", Marketing Health Services, 21 (4):18-24.

Hogan J. E., Katherina N. L., Barak L., (2004). "Quantifying the Ripple: Word of Mouth and Advertising Effectiveness", Journal of Advertising Research, 3(910):271-280.

https://www.myenocta.com, 21.03.2014.

http://pazarlama.stratejileri.com/agizdan agiza pazarlama, Erişim Tarihi: 21.03.2014.

Karaoglu H., (2010). Agizdan Agiza Isletmenin Tuketici Satin Alma Kararlari Uzerinde Etkisi ve Borusan Telekom Calisanlari Uzerinde Bir Arastirma, Kadir Has Universitesi Sosyal Bilimler Enstitusu, Isletme Anabilim Dalı. Yayinlanmamis Yuksek Lisans Tezi. Istanbul.

Kutluk A., Avcikurt C., (2014). "Agizdan Agiza Pazarlamanin Musterilerin Satin Alma Karar Sureclerine Etkisi ve Bir Uygulama: Istanbul Seyehat Acenteleri Ornegi”, Uluslararası Sosyal Araştırmalar Dergisi, 7(29): 613-622.

Odabasi Y., Baris G., (2011). Tuketici Davranisi, 6. Bask1, MediaCat Yayinlari, İstanbul.

Ulusoy G., (2014). http://www.academia.edu/6085085/Viral Pazarlama, Erisim Tarihi: 21.03.2014.

Yilmaz E., (2011). "Saglik Hizmetlerinde Agizdan Agiza Pazarlama”, Marmara Sosyal Arastirmalar Dergisi, 1(12):1-19.

Yukselen C., (2006). Pazarlama Arastirmalari, 3. Baskı, Detay Yayincilik. Ankara. 